\title{
Uwagi o storytellingu jako strategicznej koncepcji brandingu i operacyjnego narzędzia komunikacji
}

\section{Storytelling as a strategic approach of building a brand image and a tool for operational communication}

\section{Streszczenie:}

W referacie omówiono koncepcję budowania marki poprzez storytelling. Storytelling jest jedną kluczowych kompetencji w epoce kreatywnej. Wskazano elementy opowieści marki. Wskazano także przykłady marek posługujących się koncepcją storytellingu. Przedstawiono stan badań nad skutecznością koncepcji storytellingu.

Słowa kluczowe: komunikacja, techniki narracyjne, storytelling

\section{Summary:}

The aim of this article is to show the concept of branding through storytelling. The concept of storytelling as a key competence in the era of creativity. The article describes key components of brand story. It also indicated examples of brands that use the concept of storytelling. The paper presents the state of research on the effectiveness of the concept of storytelling.

Keywords: communication, narrative techniques, storytelling, 


\section{Wstęp}

Celem niniejszego artykułu jest wskazanie możliwości zastosowania storytellingu $\mathrm{w}$ biznesie $\mathrm{w}$ czasie, kiedy zacierają się granice pomiędzy PR-em, reklamą lub marketingiem. D. Pink stwierdza, iż era dominacji umysłów ścisłych już przeminęła. Przyszłość należy do innego rodzaju ludzi z innym rodzajem umysłu: do projektantów, wynalazców, nauczycieli, gawędziarzy, czyli do kreatywnych i przepełnionych empatiq prawopółkulowych myślicieli ${ }^{1}$. W epoce nawału informacji trudno nam wyselekcjonować najważniejsze i kluczowe informacje. Dlatego też E. Mistewicz jeden ze swoich artykułów zatytułował: Milion dolarów za chwilę uwagi. Skoro każdego miesiąca otrzymujemy tyle informacji ile nasi dziadkowie otrzymywali przez całe życie a w każdym wydaniu „New York Timesa” zawarte jest więcej informacji, niż przeciętny mieszkaniec siedemnastowiecznej Anglii był stanie zgromadzić w ciągu całego życia ${ }^{2}$, to pojawia się pytania, w jaki sposób zająć uwagę słuchaczy chociaż na parę chwil. Odpowiedzią na postawiony problem jest właśnie storytelling. Jest to sposób komunikowania swojej idei poprzez narrację. Narracja stosowana jest zarówno w komunikacji zewnętrznej przedsiębiorstwa, jak i w komunikacji wewnętrznej. Komunikacja wewnętrzna ukierunkowana jest na klientów, natomiast wewnętrzna dotyczy kultury organizacyjnej przedsiębiorstwa oraz postaw pracowników w nim zatrudnionych.

Storytelling może być wykorzystywany na kilku poziomach. Jednym z poziomów wykorzystania storytellingu jest niewątpliwie poziom strategiczny i w tym ujęciu storytelling może być wykorzystywany jako koncepcja brandingu. Może być również wykorzystany na

\footnotetext{
1 D. Pink, Całkiem nowy umysł. Dlaczego przyszłość należy do prawopółkulowców?, Brzezia Łąka, s. 54.

2 E. Mistewicz, Marketing narracyjny. Jak budować historie, które sprzedaja, Gliwice 2011, s. 16.
} 
poziomie operacyjnym $\mathrm{w}$ codziennej komunikacji $\mathrm{z}$ pracownikami. Takie holistyczne ujęcie storytellingu jest bliskie koncepcji prezentowanej w niniejszym artykule w oparciu o koncepcję storytellingu zaprezentowaną w książce autorstwa K. Fog, Ch. Budtz, P. Munch oraz S. Blanchette Storytelling. Narracja $w$ reklamie i biznesie ${ }^{3}$. Wskazując poniżej możliwości zastosowania storytellingu, jego elementy, strukturę maksymalną opowiadania, należy podkreślić, iż nie badano do tej pory tego zjawiska w aspekcie językoznawczym ze wskazaniem sposobu wyrażania poszczególnych elementów opowiadania.

\section{Możliwości zastosowania storytellingu}

Można wyróżnić trzy główne zastosowania storytellingu:

- Stosowanie storytellingu w przywództwie

- Stosowanie storytellingu w sprzedaży

- Stosowanie storytellingu w prezentacji.

Storytelling może być stosowany w przywództwie w celu komunikowania się z tymi, którzy powinni zostać zainspirowani. Przekonywać można poprzez stosowanie odpowiednich argumentów, ale inaczej przekonuje się poprzez historie. Poprzez opowiadanie historii przekonuje się innych na poziomie wyobrażeń, a nie polemizując z nimi. Poprzez rozmowę przekonuje się rozmówcę o jego wartości i podwyższa jego samoocenę. Uznanie przywódca może wyrazić poprzez opowieść o dokonania pracownika firmy ${ }^{4}$.

Zastosowanie storytellingu w sprzedaży prowadzi do wskazania wyższości strategii konwersacyjnej opowieści nad przekonywaniem o wartości sprzedawanego produktu. W tym kontekście należy podkreślić trudność realizacji sekwencji otwarcia dialogu, a więc powitania, przedstawienia się, zanim nastąpi przejście do oferowania pro-

\footnotetext{
${ }^{3}$ K. Fog, Ch. Budtz, P. Munch, S. Blanchette, Storytelling. Narracja $w$ reklamie i biznesie, Warszawa 2013.

${ }^{4}$ M. Stączek, Storytelling. Sztuka opowiadania przekonujacych i ciekawych historii dla lidera, trenera, sprzedawcy, Warszawa 2014, s. 22.
} 
duktu, Zgodnie z regułami komunikowania się interpersonalnego, początek konwersacji stanowi wymiana aktów etykiety językowej. Brak przekonywania klienta, a zastąpienie przekonywania do zakupu opowiedzeniem historii zmierza do spowodowania zaciekawienia klienta. Temat zostaje rozwinięty poprzez narrację. Następuje wprowadzenie do określonego zagadnienia, ukazanie tła, kontekstu danej rzeczy. Klient słucha, będąc świadomym, że nie czuje się do niczego zobowiązany. Ta część dialogu z klientem nazwana jest w literaturze dotyczącej dyskursu jako tekst ekspozycyjny ${ }^{5}$. Zastosowanie tej strategii komunikacyjnej ma na celu przekonanie odbiorcy, że nadawcy nie zależy na przedstawieniu faktów w celu osiągnięcia własnych korzyści, lecz na obiektywnym przedstawieniu rzeczywistości. Nadawca nie tworzy zatem faktów poprzez dobór argumentów w celu obrony swego stanowiska, a tworzy świat opowieści w celu uświadomienia potrzeby powiadania $\mathrm{z}$ uwzględnieniem wszystkich płynących $\mathrm{z}$ tego korzyści. Słuchacz odbiera opowiadanie jako „mniej zagrażające” od sytuacji podawania tych samych treści wprost. Poprzez opowiadania pewne treści można przekazać w sposób pośredni. M. Stączek ${ }^{6}$ opisuje pewną historię sprzedawcy ze sklepu ze sprzętem AGD. Pewnego razu w tym sklepie pojawiła się klientka z zamiarem kupienia pralki. Chciała kupić Boscha. Sprzedawca (miał na sprzedaż Whirlpoola) rozpoczął rozmowę następująco: Powiem tylko, że ten model obok - tu wskazał na pralkę Whirlpool - jest pod względem jakości identyczny, a jednak różnica to głośność podczas prania. Bosch chodzi głośniej. Nie dalej jak tydzień temu miałem sytuację, kiedy klientka wybierała między tymi modelami. Wybrała sprzęt Boscha i proszę sobie wyobrazić, na drugi dzień go odwiozła i mówi: „Proszę pana, ale ta pralka głośno chodzi! Mam małe dziecko, proszę mi jq wymienić". Zrobiłem to. Pani oczywiście sama podejmie decyzję, która pralkę wybrać.

Storytelling w prezentacji ma również bardzo wielką rangę. Tabele i wykresy w ramach prezentacji nie dają tak wiele, jak opowieść ukie-

\footnotetext{
${ }^{5}$ A. Duszak, Tekst, dyskurs, komunikacja międzykulturowa. Warszawa 1998, s. 209.

${ }^{6}$ M. Stączek, Storytelling ..., op. cit., s. 24-25.
} 
runkowana na zainteresowanie słuchacza treścią prezentacji. Poprzez storytelling zwiększa się siła perswazyjna narracji, gdyż opowiadając historie zaczerpnięte z życia, wykorzystuje się schemat przekazu, w którym coś, co się wydarzyło, równa się prawdzie ${ }^{7}$. Historia zwiększa zaangażowanie słuchacza, ze względu na funkcjonujące bodźce emocjonalne poprzez opowieść. Steve Jobs (Apple) powiedział, że „Ludzie którzy mają coś do powiedzenia, nie potrzebują PowerPoint". Natomiast Volkswagen wprowadził regułę 3 stron w prezentacjach i zakazał używania dłuższych prezentacji w Firmie.

\section{Rola historii powstania firmy w storytellingu}

Ważne miejsce $\mathrm{w}$ storytellingu zajmuje historia powstania firmy. Takie historie są wykorzystywane do pozycjonowania i promowania marek. Jedna z takich historii mówi, jak firma typu Google narodziła się „w garażu”. Historia powstania firmy Google sięga 1995 r. Dwaj matematycy rozpoczęli pracę dotyczącą wyszukiwania informacji w sięci WWW. Jeden z nich to Amerykanin Larry Page, a drugi - Rosjanin Sergey Brin. Owocem ich działań był system BackRub, który został wzbogacony o algorytm PageRank, a ten z kolei został wykorzystany w prototypie wyszukiwarki internetowej. Studenci przenieśli się z pokoju w akademiku Uniwersytetu Stanforda w Kaliforni do garażu w miejscowości Menlo Park w Kaliforni. Wyszukiwarce nadano nazwę Google w 1997 r. Nazwa ta pochodzi od terminu matematycznego googol, który oznacza cyfrę 1 i 100 zer. Termin ten odzwierciedla nieskończoną ilość informacji w Internecie.

\section{Elementy storytellingu}

Jak zaznaczają autorzy wskazanej powyżej książki, storytelling służy opowiadaniu historii. „Firmy tworzą opowieści w większości po to,

\footnotetext{
7 Ibidem, s. 25-26.
} 
aby komunikować przekaz, który odbije się pozytywnym echem dla firmowego brandu"8. Od czasów Arystotelesa aż do opowieści Jana Christiana Andersena opowieści zawierają kilka niezbędnych i obligatoryjnych elementów. Niektóre z nich mogą być fakultatywne i tworzyć wraz z obligatoryjnymi elementami makrostrukturę opowieści. Obligatoryjne elementy storytellingu to: przekaz, konflikt, postacie oraz fabuła9.

Przekaz wyznacza oś tematyczną całej historii, a opowieść staje się potwierdzeniem głównego źródła przekazu. Dzięki opowieści przekaz staje się zrozumiały. W jednej opowieści, aby stała się zrozumiała powinien zawierać się tylko jeden przekaz, a jeśli pojawi się kilka przekazów, to powinny zostać uporządkowane ${ }^{10}$.

Konflikt jest obligatoryjnym elementem opowieści, wymusza akcję, którą należy podjąć w celu przywrócenia harmonii i równowagi. W storytellingu pojęcie "konfliktowości” jest stopniowalne i może się ujawniać z większą lub mniejszą intensywnością. Im większy konflikt, tym historia ma bardziej dramatyczny charakter. Jednak istnieją granice, które nie mogą być przekraczane, gdyż historia nie może opierać się wyłącznie na chaotycznych wątkach. Konflikt ma być nazwany wprost i powinna się pojawić propozycja rozwiązania konfliktu11. Kampanie reklamowe poszczególnych marek zawierają wyrażone nie tylko w sposób eksplicytny, ale i implicytny elementy konfliktowe (kontrastujące). Np. dla firmy Dove jest to skontrastowanie prawdziwego piękna ze stereotypami wykreowanymi przez media. Dla The Economist jest skontrastowana ciekawość świata z obojętnością otoczenia. Dla firmy Logo jest to zestawienie dwóch typów rozrywki kreatywnej i zubożającej umysł ${ }^{12}$.

\footnotetext{
${ }^{8}$ K. Fog, Ch. Budtz, P. Munch, S. Blanchette, Storytelling..., op. cit., s. 43.

${ }^{9}$ Ibidem, s. 21.

10 Ibidem, s. 44.

11 Ibidem, s. 46-47.

12 M. Hajdas: Storytelling - nowa koncepcja budowania wizerunku marki w epoce kreatywnej, „Współczesne Zarządzanie/Contemporary Management Quarterly” 2011, nr 1, s. 116-123.
} 
Historia rozpoczyna się $\mathrm{w}$ tym momencie, kiedy główny bohater dąży do określonego celu. W historii pojawia się przeciwnik, który próbuje przeszkodzić bohaterowi. Bohater musi pokonać wiele przeszkód, a jedną z nich może być na przykład strach przed wspinaczką, kiedy przeszkodą do pokonania jest przeszkoda statyczna w postaci góry. Dla firmy przeszkodą mogą być klienci, którym brak zaufania wobec produktów firmy ${ }^{13}$.

Tradycyjna opowieść ma składać się z trzech części: początek, rozwinięcie, zakończenie. $\mathrm{W}$ tym miejscu podkreślić należy, iż analiza struktur typowej narracji była przedmiotem zainteresowania zarówno psychologów poznawczych, jak i literaturoznawców, semiotyków i lingwistów. Uszczegóławiając elementy struktury narracyjnej, należałoby wymienić część wstępną, zawierającą krótkie streszczenie lub zapowiedź tego, o czym będzie traktować opowieść. Po nim następuje orientacja polegająca na podaniu ogólnych ram zdarzenia lub kilku zdarzeń. Podawanie samych zdarzeń w kolejności ich przebiegu stanowi akcję. Należy podkreślić, iż sama kolejność podawanych zdarzeń jest stosowaniem perswazji. 0 wiele lepiej zapamiętujemy informacje, które podane są na początku lub na końcu, podawane są z informacjami już znanymi, są powtarzane oraz są przekazywane z widocznym entuzjazmem. Po akcji następuje ewaluacja, w której ramach podaje się własną ocenę zdarzeń, a po ewaluacji - wynik lub rozwiązanie. Całość wieńczy koda - zakończenie, które może zawierać np. pytanie „Czy coś podobnego wam się przydarzyło?”14.

\section{Modele strukturalne opowiadania}

W rozważaniach na temat storytellingu należy uwzględnić strukturę maksymalną opowiadania, wymienić jej elementy oraz opisać ich zawartość treściową: wprowadzenie, orientacja, komplikacja, rozwiązanie oraz zakończenie. Wprowadzenie stanowi początkowy element

\footnotetext{
${ }^{13}$ K. Fog, Ch. Budtz, P. Munch, S. Blanchette, Storytelling..., op. cit., s. 50.

14 I. Kurcz, I., Psychologia języka i komunikacji, Warszawa 2000, s. 170.
} 
opowiadania i komunikuje początek zdarzeń15. Zakreślona zostają w ten sposób ramy tematyczne tekstu, zwięzłe streszczenie ma wzbudzić zainteresowanie odbiorcy. Aby opowiadanie zostało wydzielone $\mathrm{z}$ całości dialogu, należy $\mathrm{w}$ tekście umieścić sygnały ramowe, tj. formuły wstępne, formuły przygotowujące. Rama taka zawiera wyrażone eksplicytnie delimitatory, które dzielą się na sygnały (wyrażenia leksykalne o charakterze metatekstowym przekazujące informację o tym, że tekst się rozpoczyna lub kończy (np. Swojq historię zacznę od...) oraz symptomy delimitacyjne (np. a więc, z kolei, a zatem). $\mathrm{W}$ ramach kolejnego etapu opowiadania, tj. orientacji nadawca informuje o sytuacji wyjściowej, umiejscawia wydarzenia w czasie i przestrzeni, prezentuje cechy bohaterów, wskazuje punkty odniesienia, ułatwiające odbiorcy rozpoznanie znanych przedmiotów lub osób, tłumaczy sens zdarzeń oraz zachowań bohaterów. Z kolei komplikacja dotyczy zmian $\mathrm{w}$ działaniach lub stanach psychicznych bohaterów spowodowanych nagłymi i nieoczekiwanymi wydarzeniami ${ }^{16}$. Komplikacja może być sygnalizowana poprzez wykładniki leksykalne (nagle, zaraz, wtem, w pewnym momencie), wykładniki syntaktyczne (użycie konstrukcji przeciwstawnych), wykładniki fleksyjne (użycie form praesens historicum). W rozwiązaniu przedstawiane są efekty działań opisanych wcześniej. Jest to składnik obligatoryjny opowiadania, ponieważ bez niego historia byłaby niepełna. W zakończeniu wyraża się w sposób eksplicytny sfinalizowanie czynności opowiadania. Analizując przykłady storytellingu, można będzie odpowiedzieć na pytanie: Czy w storytellingu wykorzystany jest schemat narracji amerykańskich socjolingwistów, czy uwzględniana specyfika polskich opowiadań z punktu widzenia ich struktury dostosowanej do naszego kręgu kulturowego? Jaka jest tendencja w tym zakresie? Mam tutaj na uwadze prace W. Labova i J. Waletzky'ego: Narrative Analysis: Oral Version

15 W. Labov, Some Further Steps in Narrative Analysis, „Journal of Narrative and Life History" 1997, nr 1-4, s. 207-215.

16 T. A. van Dijk, Działanie, opis działania a narracja, [w:] Narratologia, M. Głowiński (red.), Gdańsk 2004, s. 161. 
of Personal Experience ${ }^{17}$ oraz W. Labova: Some Further Steps in Narrative Analysis ${ }^{18}$; Uncovering the Event Structure of Narrative ${ }^{19}$; Narrative Pre-construction ${ }^{20}$ i porównanie $\mathrm{z}$ badaniami tekstów polskich ${ }^{21}$.

\section{Analiza opowieści skonstruowanej na podstawie własnych doświadczeń}

Jednym z przykładów, które stosuję w trakcie storytellingu jest opowieść o wybranym przypadku, którą wplatam w trakcie rozmowy z potencjalnym klientem. Opowieści staram się nadać odpowiednią narrację przy wykorzystaniu metody greenlight. W opowieści pojawiają się elementy, z którymi łatwo może zidentyfikować się mój rozmówca, tak jak identyfikuje się np. z hollywoodzką historią, którą ogląda w na ekranie kina. Tymi elementami są:

- Bohater, który posiada cechy na tyle uniwersalne, że może się z nimi identyfikować osoba, do której skierowana jest opowieść.

- Katalizator to usługa, którą posiadam w swojej ofercie. W przypadku, który opisuję poniżej, jest to usługa „Google Zdjęcia” zintegrowana z usługą „Google Drive” (wirtualny dysk w chmurze obliczeniowej Google). Bohaterem opowieści nie jestem ja.

- Konflikt - rozpoznanie wyzwania, z którym spotyka się mój bohater. Bohater używa katalizatora do rozwiązania problemu.

- Linia mety to punkt, w którym bohater mojego opowiadania dochodzi do rozwiązania problemu.

17 W. Labov, J. Waletzky, Narrative Analysis: Oral Versions of Personal Experience [w:] Essays on the Verbal and Visual Arts. Proceedings of the 1966 Annual Spring Meeting of the American Ethnological Society, J. Helm (red.), Seattle-London, s. 12-44.

18 W. Labov, Some Further Steps..., op. cit., s. 207-215.

19 W. Labov, Uncovering the Event Structure of Narrative [w:] Linguistic, Language, and Real World: Discourse and Beyond. Georgetown University Round Table on Languages and Linguistics, D. Tannen, J. E. Alatis (red.), Washington 2001.

20 W. Labov, Narrative Pre-construction. „Narrative Inquiry” 2006, nr 16, s. 37-45. 2008.

${ }^{21} \mathrm{~J}$. Labocha, Tekst, wypowiedź, dyskurs procesie komunikacji językowej, Kraków 
Cezary Augustynowicz - Uwagi o storytellingu...

- Wnioski - nauka jaką wyciąga z zastosowania katalizatora nie tylko bohater ale również mój rozmówca.

Poniżej zamieszczam informacje, które przekazuję czytelnikowi niniejszego artykułu, zawierające historię opowiadaną klientowi. W sposobie przekazywania informacji tworzy się opowieść dotycząca firmy jednego z moich klientów:

Przykładowa historia to pewna historia dotyczaca firmy mojego klienta zajmującej się instalacją stacji bazowych dla jednego z operatorów telefonii komórkowej na terenie Niemiec. Firma posiada monterów, którzy $w$ kilkuosobowych zespołach codziennie wyjeżdżaja na montaż anten do telefonii 4. generacji LTE. Firma mojego klienta posiada zobowiazania $w$ stosunku do swojego zleceniodawcy $w$ postaci odpowiednio przygotowanej dokumentacji zawierającej zdjęcia z zamontowanych stacji bazowych, z których $w$ przypadku napraw gwarancyjnych korzystaja operator, firma mojego klienta lub inni zleceniobiorcy. Montażyści na różnych etapach wykonywanych prac wykonuja zdjęcia za pomoca aparatów cyfrowych. Po powrocie do bazy (firmy) podłączaja swoje aparaty cyfrowe za pomoca kabla USB do komputerów i przesyłaja pliki ze zdjęciami na dyski lokalnego serwera. Pliki zdjęciowe o dużej rozdzielczości zajmuja jednak sporo miejsca na dyskach i co jakiś czas dział IT musi dokonywać upgrade'u systemów o nowe pojemniejsze dyski. Do tego firma ponosi spore koszty na licencje oprogramowania do zarzadzania plikami. Wszystkie dane musza być również zachowane $w$ kopiach zapasowych na wypadek zhackowania lub awarii systemu. Wywiązywanie się ze zobowiązań w stosunku do operatora, wymaga ponoszenia co raz to wyższych nakładów pieniężnych jak również pracy działu IT.

Mój klient zaczął się rozglądać za jakimś alternatywnym systemem, rozwiq̨ującym problem ciągłego powiększania własnej przestrzeni dyskowej oraz skomplikowanej i czasochłonnej procedury przenoszenia zdjęć na dyski. W trakcie poszukiwań natknął się na usługę „Google Zdjęcia”, która zintegrowana jest z każdym $w$ miarę nowoczesnym smartfonem, w który wyposażony jest każdy jego monter. Do tego 
smartfony posiadajq również aparaty fotograficzne o bardzo dobrej rozdzielczości, nie słabszej jak dotychczas stosowane $w$ firmie dedykowane cyfrowe aparaty fotograficzne. Przy użyciu smartfonu i usługi „Google Zdjęcia” oraz „Google Drive” (Dysk) zdjęcia po uprzedniej konfiguracji aplikacji aparatu na smartfonie kopiujq się automatycznie na Dysk Google. „Google Drive” oferuje w taryfie, która posiada klient nieograniczonq przestrzeń dyskową i problem brakującej pamięci przestaje $w$ tym momencie istnieć. $W$ trakcie wykonywanych zdjęć aparat $w$ smartfonie dodaje dodatkowe informacje meta do wykonanych zdjęć takich jak data, czy GEO-Pozycja. Umożliwia to bardzo szybkie wyszukanie zdjęcia $w$ przypadku konieczności wykonania usługi serwisowej. Również dostarczenie dokumentacji do operatora jest bardzo proste, gdyż ogranicza się tylko do udostępniania mu dostępu do odpowiednich plików zdjęciowych

Lekcja, jakq wyciaga mój rozmówca jest to, że za pośrednictwem narzędzi, które posiadam $w$ ofercie udaje się $w$ prosty sposób rozwiq̨zać bardzo poważny problem mojego klienta. Podobna sytuacja może istnieć lub istnieje również u mojego rozmówcy. Moja opowieść nie jest fikcyjna i mój rozmówca może odbyć rozmowę referencyjnq z moim klientem, co podnosi wiarygodność mojej opowieści. Opowieść nie trwa dłużej jak 3 do 4 minut.

Poniższą opowieść otwiera wprowadzenie, które - jako początkowy element opowiadania komunikuje początek zdarzeń, odpowiada na pytanie „o czym traktuje ta opowieśc”. Wprowadzenie ma przedstawić słuchaczowi temat opowieści: Przykładowa historia to pewna historia dotycząca firmy mojego klienta. Po krótkim wprowadzeniu następuje orientacja, w której na plan pierwszy wysuwa się funkcja opisowa i identyfikacyjna. Opis dotyczy zakresu działalności firmy, w którym pojawia się lokalizacja przestrzenna (na terenie Niemiec). W części opisowej pojawia się charakterystyka działalności firmy (monterzy $w$ kilkuosobowych zespołach codziennie wyjeżdżajq na montaż anten do telefonii 4. generacji LTE; zobowiązań firmy, charakterystyki działalności montażystów, którzy na różnych etapach wykonywa- 
nych prac wykonują zdjęcia za pomocq aparatów cyfrowych). W komplikacji wskazuje się na trudności spowodowane przez wydarzenia niekorzystne dla firmy, co powoduje konieczność zwiększenia wydatków przez firmę (Pliki zdjęciowe o dużej rozdzielczości zajmuja jednak sporo miejsca na dyskach i co jakiś czas dział IT musi dokonywać upgrade'u systemów o nowe pojemniejsze dyski).

Jako kolejny element pojawia się rozwiązanie (co się ostatecznie stało?). Jest to dla tego opowiadania kluczowy moment, gdyż przynosi informacje o efektach przyjętych rozwiązań. Wyróżnia się kilka typów rozwiązania: niepowodzenie, powodzenie osiągnięte przez przypadek, a także powodzenie osiągnięte dzięki podjęciu działań22. Klient „zaczął się rozglądać za jakimś alternatywnym systemem” w celu rozwiązania problemu, „W trakcie poszukiwań natknął się na usługę „Google Zdjęcia”. W rezultacie poszukiwań dowiedział się, jak uzyskiwać nieograniczoną przestrzeń dyskową „i problem brakującej pamięci przestaje $w$ tym momencie istnieć". W zakończeniu mogą pojawić się elementy, za pomocą których narrator powiadamia odbiorcę o zakończeniu opowieści, zamknięciu sytuacji narracyjnej i powrocie do sytuacji "tu i teraz". Koda w tym opowiadaniu to końcowy akapit, w którym nawiązuję do sytuacji narracyjnej po zakończeniu opowiadania. Po przejściu do sytuacji „tu i teraz” następuje element aksjologiczny zawierający komponenty: „prostota oferowanych narzędzi rozwiązanie bardzo poważnego problemu". Dzięki takiemu w sposób maksymalnie skontrastowanemu zestawieniu, podwyższa się poziom wiarygodności przekazywanej historii. W części finalnej tekstu zawarty jest komentarz wskazujący sposób uwiarygodnienia opowieści i wskazanie na czas jej trwania w warunkach rozmowy z klientem.

\section{Zakończenie}

W zakończeniu chciałbym zaproponować realizację projektu badawczego, który dotyczyłby analizy elementów pojawiających się

22 T.A. van Dijk, Działanie, opis działania a narracja..., op. cit., s. 162. 
w storytellingu z perspektywy lingwistycznej. Można badać środki językowe wykorzystywane w każdej z części opowiadania, a storytelling umiejscowić w różnych fazach rozmowy z klientem. Badania dotyczyłyby również wyznaczenia prawidłowości z jednej strony między stosowaniem różnorodnych środków językowych w storytellingu i umiejscowieniem go w fazach rozmowy, a skutecznością rozmowy z klientem przy analizie fazy otwarcia, oferowania oraz zamknięcia. Rozmowa z klientem to dynamiczny ciąg zachowań językowych, a stosowanie strategii komunikacyjnych $w$ tej rozmowie uzależnione jest od kompetencji zawodowych, komunikacyjnych i - co dla naszych rozważań jest szczególnie ważne - narracyjnych. W ramach realizacji wskazanego projektu można byłoby wskazać, jak kształtować i doskonalić kompetencje narracyjne storytellerów w celu zwiększenia skuteczności ich działań. Prowadzone szkolenia w tym zakresie nie uwzględniają bardzo ważnego aspektu w storytellingu, tj. aspektu lingwistycznego, który wskazuje na zasadność stosowania różnorodnych środków językowych w celu maksymalizacji sukcesu storytellerów.

\section{Bibliografia:}

Bargiel-Chiappni F. (red.), The Handbook of Business Discourse, Edinburgh University Press, Edinburgh 2009.

Barthes R., Wstęp do analizy strukturalnej opowiadania [w:] Antropologia twórczości słownej, A. Karpowicz (red.), Wydawnictwo Uniwersytetu Warszawskiego, Warszawa 2010.

Boje, D. M., The storytelling organization: A study of story performance in an office supply firm, „Administrative Science Quarterly” 1991, nr 1.

Boje D. M., STORIES of the Storytelling Organization: A Postmodern Analysis of Disney as „Tamaraland”, „Academy of Management Journal” 1995, nr 4.

Boje D. M., Narrative Methods for Organizational and Communication Research, Sage Publications, London 2001.

Boje D. M., Storytelling Organizations, Sage Publications, London 2008.

Boje D. M., The Future of Storytelling and Organizations: An Antenarrative Handbook, Routledge, New York-London 2011. 
Cezary Augustynowicz - Uwagi o storytellingu...

Boje D. M., Tourani N., Storytelling, czyli o materialności praktyk opowiadania, [w:] Badania jakościowe. Podejścia i teorie, D. Jemielniak (red.), Wydawnictwo Naukowe PWN, Warszawa 2012.

Czarniawska, B., Narratives in social science research, Sage, London-Thousand Oaks-New Delhi 2004.

Denning S., The Springboard. How Storytelling Ignites Action in Knowledge Era Organizations, Routledge, London 2000.

Dijk T. A. van, Działanie, opis działania a narracja, [w:] Narratologia, M. Głowiński (red.), wyd. Słowo/Obraz Terytoria, Gdańsk 2004.

Dijk T.A. van (red.), Dyskurs jako struktura i proces, Wydawnictwo Naukowe PWN, Warszawa 2001.

Duszak A., Tekst, dyskurs, komunikacja międzykulturowa, Wydawnictwo Naukowe PWN, Warszawa 1998.

Dziob A., Badanie narracji - miedzy psychologia, socjologia a językoznawstwem, „Kwartalnik Językoznawczy” 2010, nr 2.

Emmott C., Narrative Comprehension: A Discourse Perspective, Oxford University Press, Oxford 1997.

Fisher W., Paradygmat narracyjny [w:] E. Griffin (red.), Podstawy komunikacji społecznej, Gdańskie Wydawnictwo Psychologiczne, Gdańsk 2009.

Flannery M.S., „She discriminated against her own race”. Voicing and identity in a story of discrimination, „Narrative Inquiry” 2008, nr 1.

Florida R., The Rise of the Creative Class, and How it's Transforming Work, Leisure, Community, and Everyday Life, Basic Books, New York 2002.

Fludernik M. The Historical Present Tense Yet Again: Tense Switching and Narrative Dynamics in Oral and Quasi-Oral Sorytelling, „Text” 1991, vol. 11, nr 3.

Fludernik M., Towards a „Natural” Narratology, Routledge, London 1996.

Fog K., Budtz C., Yakaboylu B., Storytelling. Branding in Practice, Springer, Berlin 2005.

Fog K., Budtz Ch., Munch Ph., Blanchette S., Storytelling. Narracja w reklamie i biznesie, wyd. Saatchi \& Saatchi, Warszawa 2013.

Frawley W., Linguistic Semantics, Lawrence Erlbaum, Hillsdale 1992.

Gabriel Y., Storytelling in Organizations - Facts, Fictions and Fantasies, Oxford University Press, Oxford 2000.

Hajdas M., Storytelling - nowa koncepcja budowania wizerunku marki w epoce kreatywnej, „Współczesne Zarządzanie / Contemporary Management Quarterly" 2001, nr 1. 
Jung G., Archetypy i symbole, Wydawnictwo „Czytelnik”, Warszawa 1993.

Kurcz, I., Psychologia języka i komunikacji, Wydawnictwo Naukowe „Scholar” Warszawa 2000.

Labocha J., Tekst, wypowiedź, dyskurs procesie komunikacji językowej, Wydawnictwo Uniwersytetu Jagiellońskiego, Kraków 2008.

Labov W., Some Further Steps in Narrative Analysis, „Journal of Narrative and Life History" 1997, nr 1-4.

Labov W., Uncovering the Event Structure of Narrative [w:] Linguistic, Language, and Real World: Discourse and Beyond. Georgetown University Round Table on Languages and Linguistics, D. Tannen, J. E. Alatis (red.), Georgetown University Press, Washington 2001.

Labov W., Narrative Pre-construction, „Narrative Inquiry” 2006, nr 16.

Labov W., Waletzky J., Narrative Analysis: Oral Versions of Personal Experience [w:] Essays on the Verbal and Visual Arts. Proceedings of the 1966 Annual Spring Meeting of the American Ethnological Society, J. Helm (red.), University of Washington Press, Seattle-London1967.

Lyons, J., Semantyka. T. I-II, Państwowe Wydawnictwo Naukowe, Warszawa: 1989.

Mistewicz E., Marketing narracyjny. Jak budować historie, które sprzedaja, Wydawnictwo Helion Gliwice 2011.

Pellowski, A., The World of Storytelling: A Practical Guide to the Origins, Development and Applications of Storytelling, The H. W. Wilson Co, New York 1990.

Pink D., Całkiem nowy umysł. Dlaczego przyszłość należy do prawopółkulowców?, Wydawnictwo Poligraf, Brzezia Łąka 2009.

Poulton M.S., Organizational Storytelling, Ethics and Morality: How Stories Frame Limits of Behavior in Organizations, „Electronic Journal of Business Ethics and Organization Studies” 2005, nr 2.

Rosen E., Fama. Anatomia marketingu szeptanego, wyd. Media Rodzina, Poznań 2003.

Ryan M.-L., Narrative across Media. The Languages of Storytelling. University of Nebraska Press, Lincoln 2004.

Stączek M., Storytelling. Sztuka opowiadania przekonujących i ciekawych historii dla lidera, trenera, sprzedawcy, wyd. EdisonTeam.pl, Warszawa 2014.

Wurman R.S., Information Anxiety, Doubleday, New York 1989. 